\title{
TOXOPLASMA GONDII ISOLAMENTO A PARTIR DE CARNE E CÉREBRO DE SUÍNOS COMERCIALIZADOS NA REGIĀO DE LONDRINA - PR
}

\author{
NAVARRO, I.T: \\ VIDOTTO, O. \\ GIRALDI, N, \\ FREIRE, R.L.
}

NAVARRO, I.T. et al. Toxopkasma gondii: isolamento a partir de carne e córebro de sufnos comerclalizados na regiăo de Londrina - Pr. Sermina: Ci. Agr., Londrina, v. 13, n. 1, p. 32-34, mar. 1992.

\section{RESUMO}

Tem sido constatado que a infecçăo toxoplásmica é altamente prevalente nos rebanhos de suinos da região de Londrina, PR. O consumo desta came na regiāo, por sua vez, é significativo; quer "in natura", quer na forma de embutidos. Assim, no presente trabalho, procedeu-se à colheita em açougues, de 153 amostras de suínos, 117 de músculo e 36 de cérebro. O material foi processado e inoculado em camundongos albinos. Após o período de observação os camundongos foram sangrados e o material submetido a Reação de Imunofluorescencia Indireta (RIFl), para detecção de anticorpos anti T. gondii (IgG). Verificou-se 23 $(19,66 \%)$ amostras de carne positivas e $8(22,22 \%)$ de cérobro. Estes resuitados evidenciam a importância da espécie suína como fonte de infecção da toxoplasmose humana na regiāo estudada.

PALAVRAS-CHAVE: Toxoplasmose; Súnos; Cames.

\section{1 - INTRODUÇÃO}

O Toxoplasma gondii, (NICOLLE \& MANCEAUX, 1909), parasita intracelular obrigatório, é o causador da toxoplasmose, enfermidade que acomete o homem e todos os animais de sangue quente jâ postos à prova. APTL (1987) apud NAVARRO (1987) considera esta antropozoonose como a parasitose mais frequente no homem e, talvez, nos animais homeotermos. A extensa infestação por T. gondii no ser humano é determinada pela alta distribuiçăo da enfermidade nas diferentes espécies de animais domésticos e selvagens, principalmente nos suínos. Nesta espécie é comum a ocorre̊ncia da infecçäo, na maioria das vezes assintomática ou causando sintomatologia branda (AMARAL \& MACRUZ, 1969; VIDOTTO et alii, 1987a,b; VIDOTTO et alii, 1990).

O homem pode adquirir a infecçăo por três vias, principalmente: a) ingestão de oocistos oriundos de fezes de felfdeos, já esporulados no meio ambiente (solo, areia, água); b) ingestāo de cistos teciduais viáveis, presentes na carne ou em sub-produtos destas, sobretudo cruas ou mal-cozidas; c) infecçăo transplacentária (FRENKEL, 1971 e 1973).

Segundo KI MBALL et alii (1986) apud DUBEY (1986), dados epidemiológicos sugerem que a ingestão de cistos teciduais em carnes mal cozidas ou cruas, é uma importante via de infecção para o ser humano. Em um estudo, a porcentagem de pessoas com infecçảo toxoplásmica foi mais elevada nas populaçôes que tinham o hábito de consumir carnes mal cozidas.

Na região de Londrina, trabalhos de VIDOTTO et alii (1986 e 1990), demonstraram a alta ocorrência de suínos sorologicamente positivos para toxoplasmose. Em animais encaminhados a abatedouros da região, detectaram um fndicee de $34,62 \%$ de soro-positivos. Em granjas da regiäo, trabathando com todas as faixas etárias, apuraram $37,84 \%$ de soro-reagentes. Embora na maioria dos casos não haja uma correlação do tftulo com sintomatologia clínica, tem sido observado, em rebanhos positivos, a ocorrencia de abortos, elevada mortalidade em leitóes recém-nascidos, entre outros distúrbios reprodutivos.

A distribuiçăo dos cistos nos vários tecidos dos sulnos năo é homogênea. Há um maior número no cérebro e coração, e menos em língua, músculos lisos, diafragma, rins e ffgado (FAYER \& DUBEY, 1985).

Uma vez que se encontra suficientemente documentado o tato de que a carne suína é uma das principais causas de transmissăo do $\mathrm{T}$. gondii ao homem, notadamente em regióes onde o rebanho suíno apresenta tftulos sorológicos elevados, o presente trabalho visa quantificar o potencial de infecção por carnes de suínos comercializadas em açougues do municipio de Londrina e regiăo.

AMARAL \& MACRUZ (1969), determinaram um índice de $32 \%$ de positividade em diafragmas de suinos por eles amostrados em abatedouros da cidade de São Paulo. Para regiäo de Londrina, porém, não se encontrou trabalhos desta natureza e o presente estudo vem preencher esta lacuna na epidemiologia da toxoplasmose na região.

\section{2 - MATERIAL E MÉTODOS}

Foram colhidas ao acaso, em açougues da regiăo, 117 amostras de carne e 36 amostras de cérebro de suínos oriundas de criações da regiâo. O número de amostras colhidas representou $50 \%$ dos estabelecimentos de todas as categorias e foram distribuldos por todos os bairros das cidades da regiẫo considerada (Londrina, Cambé e Rolândia). As

a. Trabalho financiado pelo Conselho de Ciência e Tecnologia do Estado do Paraná. (CONCITEC)

b. Departamento Medicina Veterinấria Preventiva - CCAVUniversidade Estadual de Londrina, Caixa POstal 6001, CEP 86051 -970, Londrina - Pr - Brasil. 
amostras eram constituidas de 50 gramas de várias porçōes do encéfalo ou de vários cortes da economia animal, livres de gorduras.

As amostras de $50 \mathrm{~g}$ de carne foram submetidas à digestăo péptica artificial adicionando-se 5 volumes da soluçăo constitulda por $2,5 \mathrm{~g}$ de pepsina (atividade biológica 1:10000), $5,0 \mathrm{~g}$ de $\mathrm{NaCl}, 70 \mathrm{ml}$ de $\mathrm{HCl}$ e água destilada q.s.p. $500 \mathrm{ml}$ de solução. $O$ homogeneizado foi incubado $37^{\circ} \mathrm{C}$ sob agitaçāo por 90 minutos, após filtrado em gaze duplo estéril (DUBEY, 1988).

Os volumes filtrados foram centrifugados a $4000 \mathrm{rpm}$ por 10 minutos, o sobrenadante desprezado e o sedimento ressuspenso em soluçăo salina $(0,9 \% \mathrm{NaCl})$ para completar $50 \mathrm{ml}$. Apos repetir este procedimento duas vezes, o sedimento foi ressuspenso em $10 \mathrm{ml}$ de salina contendo 1000 $\mathrm{Ul} / \mathrm{ml}$ de penicilina $\mathrm{G}$ e $1 \mathrm{mg} / \mathrm{ml}$ de dihydroestreptomicina. A suspensão assim obtida foi inoculada por via intraperitoneat na dosagem de $2 \mathrm{ml}$ para cada camundongo $(n=5)$ albinos "swiss", fêmeas, com peso entre 25 e $30 \mathrm{~g}$, e comprovadamente livres de anticorpos anti-T. gondii.

Paralelamente, as amostras de cerrebro foram trituradas em gral esterilizado, junto com salina estéril. De cada amostra, após a adição de salina com antibiótico, inoculou-se em camundongos conforme procedimento utilizado para as amostras de carnes. Os camundongos inoculados foram observados diariamente por 40 dias, e entre aqueles com sintomatologia, retirou-se o exudato peritoneal e órgẩos (cêrebro, ffgado e pulmōes) que, apos exame a fresco, foram reinoculados em outros 3 camundongos pela mesma via. Os lotes de camundongos sobreviventes, após o perlodo de observaçāo de 40 dias, foram sangrados, sendo os soros obtidos submetidos à Reação de Imunofluorescência Indireta (RIFI), para pesquisa de anticorpos anti- $\mathrm{T}$. gondii, sendo considerado positivos os que apresentaram ttulo maior ou igual a 1:16. O conjugado utilizado para a RIFI foi $\lg G$ anticamundongo na diluição de 1:40 (Sigma Chemical).

\section{3 - RESULTADOS}

A tabela 01 apresenta os resultados obtidos no isolamento de $T$. gondii em 117 amostras de carne de suíno comercializados na regiāo de Londrina, PR. Isolou-se T.' gondii em $3,42 \%$ das amostras $(n=4)$, em épocas e oriundas de locais diferentes, embora nāo tenha identificado as propriedades de origem dos animais. Das amostras de cérebro não houve nenhum isolamento direto do agente, apos inocoulação nos camundongos.

A detecção de anticorpos anti- $T$. gondii, através da RIFI (thilo $1: 16$, representou $16,24 \%$ entre as amostras estudadas. Somando-se às 4 amostras do isolamento direto, obtęm-se 23 amostras positivas $(19,66 \%)$.

As 36 amostras de cerebro apresentaram um findice de $22,22 \%$, ou seja, 8 amostras resultaram em titulos positivos na RIFI.

No total, carne e cerebro, temos 31 positivos $(20,26 \%)$, como mostra a Tab. 01.

\section{4 - DISCUSSĀO}

Considerando-se que $34,62 \%$ dos suínos abatidos na região são portadores de titulos sorologicos para toxoplasmose (VIDOTTO et alii, 1986), os números levantados no presente trabalho parecem inferir com a expectativa. Há que se considerar que em trabalhos desta natureza pode-se faIhar na tentativa de identificar animais portadores de cistos de T. gondii. A amostra é reduzida e há a possibilidade de perdas durante a digestăo péptica.

O percentual de $20,26 \%$ de isolamentos (direto e indireto) nas amostradas estudadas e de alto significado do ponto de vista de saúde pública (DUBEY, 1988), ficando evidenciado o risco de infecção toxoplásmica à população conforme ressaltado por (AMARAL \& MACRUZ, 1969; VIDOTTO et alii, 1986; DUBEY, 1988). Mesmo que na região pesquisada näo seja disseminado o consumo de carne mal cozida, \& de grande importåncia o risco do consumo de linguiças $e$ outros embutidos da cozinha tradicional, como ficou demonstrado por NAVARRO (1987), que realizou estudos de infectividade com carne tresca e linguiça frescal de sulnos. Tais produtos são elaborados em grande escala na regiảo e, năo raramente, consumidos mal cozidos e mesmo crús.

A toxoplasmose e uma zoonose que năo pode ser diagnosticada rotineiramente na linha de matança, nos abatedouros. Com isto, a prevenção da infecção da população humana déve ser realizada a dois niveis; o primeiro na granja, com medidas que impeçam a infecçāo dos animais; a segunda a nivel de consumidor, com práticas que minimizem a possibilidade de contágio. $O$ consumidor deve ser alertado para os seguintes fatos: näo se deve provar carne crua ou

\section{TABELA 01 \\ RESULTADOS DE ISOLAMENTO DE TOXOPLASMA GONDII A PARTIR DE CARNE E CÉREBRO DE SUÍNOS COMERCIALIZADOS NA REGIÃO DE LONDRINA - PR}

OBSERVAÇĂO

\begin{tabular}{lrlrr}
\cline { 3 - 5 } AMOSTRAS & No & DIRETO* & INDIRETO** & TOTAL \\
\hline Carne & 117 & $04(3,42 \%)$ & $19(16,24 \%)$ & $23(19,66 \%)$ \\
Cérebro & 36 & 00 & $08(22,22 \%)$ & $08(22,22 \%)$ \\
\hline TOTAL & 153 & $04(2,61 \%)$ & $27(17,65 \%)$ & $31(20,26 \%)$ \\
\hline
\end{tabular}

* isolamento de taquizoito do exudato peritoneal de camundongos.

** RIFl maior ou igual a 1:16 em camundongos inoculados.

Semina: Ci. Agr., Londrina, v. 13, n. 1, p. 32-34, mar. 1992 
em cozimento; lavar as māos e os utensfios de cozinha após manipular carne crua (DUBEY, 1986); as linguiças frescais devem receber quantidades adequadas de sal $(2,0$ a $2,5 \%)$ e descansar por 48 horas, para que haja a inativaçảo dos cis- tos (NAVARRO, 1987). Com estas medidas simples, podese evitar, em grande parte, contrair toxoplasmose atraves de ingestäo de carnes. No entanto, restam outras fontes e vias de infecçăo para serem melhor avaliadas em nosso meio.

NAVARRO, L.T. et al. Toxoplasma gondii: isolamento a partir de carne e cérebro de sufnos comercializados na regltio de Londrina - Pr. Semina: Cl. Agr., Londrina, v. 13, n. 1, p. 32-34, mar. 1992.

\section{ABSTRACT}

The toxoplasma infection has been verified in high frequence in pigs from Londrina region, State of Paraná, Brazil. The consumption of fresh or industrialized pork in the region is significant. Thus, samples of pork were obtained in butcheries (117 muscle and 36 brain). The tissues were processed and inoculated in mice. The sera obtained from these mice were submitted to IFA for the detection of antibody anti-T. gondis ( $\mathrm{gGG} .23(19,66 \%)$ positive samples were found in the meat and 8 (22,22\%) positive samples were found in the brains. These results demonstrate the importance of the pigs as a source of $T$. gondis infection in human beings in the region.

KEY-WORDS: Toxoplasma; Pork; Meat; Pigs.

\section{REFERÊNCIAS BIBLIOGRÁFICAS}

1. AMARAL, V. \& MACRUZ, R. Toxoplasma gondii, isolamento de amostras a partir de diafragmas de suinos clinicamente sadios, abatidos em matadouros de Săo Paulo-Brasil. Arg. Inst Biol., 36(1): 47-54, 1969.

2. DUBEY, J.P. Toxoplasmosis. J. Am, Vet Med. Assoc., 189(2): 166-170, 1986.

3. DUBEY, J.P. Long-term persistence of Toxoplasma gondii in tissues of pigs inoculated with $T_{+}$gondii oocysts and effects of freezing on viability of tissues cysts in pork. Am, I. VeL Res., $49(6)$ : 910-913, 1988.

4. FAYER, R. \& DUBEY, J.P. Methods for controlling transmission of prolozoan parasits from meat to man. Food. Technol., 39(3): 57-60, 1985.

5. FRENKEL, J.K. Toxoplasmosis; mechanisms of infection, laboratory diagnosis and management. Cur. Trop. Path, (54): 28-75, 1971.

6. FRENKEL, J.K. Toxoplasma in and around us. Bioscience, (23): $343-352,1973$.

7. NAVARRO, I.T. Estudo da resisténcia do Toxoplasma gondii (Nicolle \& Manceaux, 1909) ao efeito do cloreto de śdio e condimentos om finguica frescal de sulno. Bol, OL Sarit, Panam. 112(2): 138-144, 1992. 1987. 61p.

8. VIDOTTO, O.; NAVARRO, I.T.; MOCO, C.A.; PINCELLI, C.A.; NISHIMURA, M.F. da C. Prevaléncia de Toxoplasma gondit em sufnos abatidos em matadouros no norte do Paraná. In: ENCONTRO DE PESQUISAS VETERINÁRIAS, 2, Londrina, 20 a 24 out. 1986. Anais... Londrina, 1986.

9. VIDOTTO, O.; COSTA, A.J.; BALARIN, M.R.S.; ROCHAS, M.A. Toxoplasmose experimental em sufnos. 1. Observaçöes clínicas e hematológicas. Arq. Bras. Med, Vet. Zoot, 39(4): 623-639, 1987a.

10. VIDOTTO, O.; COSTA, A.J.; REIS, A.C.F.; VIOTTI, N.M.A. Toxoplasmose experimental em suínos. Il. Alteraçס̃os patológicas e reisolamento. Arq. Bras, Med. Vet Zoot, 39(5): 795-814, $1987 \mathrm{~b}$.

11. VIDOTTO, O.; NAVARRO, I.T.; GIRALDI, N.; FREIRE, R.L.; MITSUKA, R. Estudos epidemiológicos da toxoplasmose em suínos da regiăo de Londrina - PR. Semina, $11(1)$ : $53-59,1990$.

Recebido para publicaçăo em 16/7/1991 